\title{
1. Transport priorities shaping the urban fabric: new methods and tools
}

Peter Newman

\section{INTRODUCTION}

Sustainability for cities can be understood as the process of reducing the footprint of urban development whilst improving liveability (Newman \& Kenworthy, 1999). Figure 1.1 schematically describes the city as a process of inputs, dynamics and outcomes, both positive and negative. The city's footprint can be lowered by reducing the resource inputs and waste outputs while increasing the liveability through better housing, community, health and economic benefits. Transport - a major part of settlements - is the key to understanding and managing city dynamics. This chapter examines how transport infrastructure shapes cities. It also shows how sustainability can be improved by better planning and assessment of transport infrastructure. The chapter uses the newly developed theory of urban fabrics (Newman \& Kenworthy, 2015; Newman et al., 2016) as the basis of creating a set of methods for sustainable transport planning and assessment (Newman et al., 2009; Newman, 2013).

\section{UNDERSTANDING CITIES: URBAN FABRIC THEORY}

Marchetti (1994) and Zahavi and Talvitie (1980) were among the first to show that there is a universal travel-time budget of a little over one hour on average per person per day. This Marchetti constant has been found to apply in every city studied; it holds true in all 100 or so cities in our Global Cities Database (Kenworthy \& Laube, 2001) as well as in data on UK cities for 600 years (SACTRA, 1994). It helps to understand how cities are shaped and how they can be transformed for agendas such as sustainability (Newman \& Kenworthy, 1999, 2006, 2015). Cities grow to being about one-hour wide based on the speed by which people can move in them. If cities go beyond this, they start to become dysfunctional and 


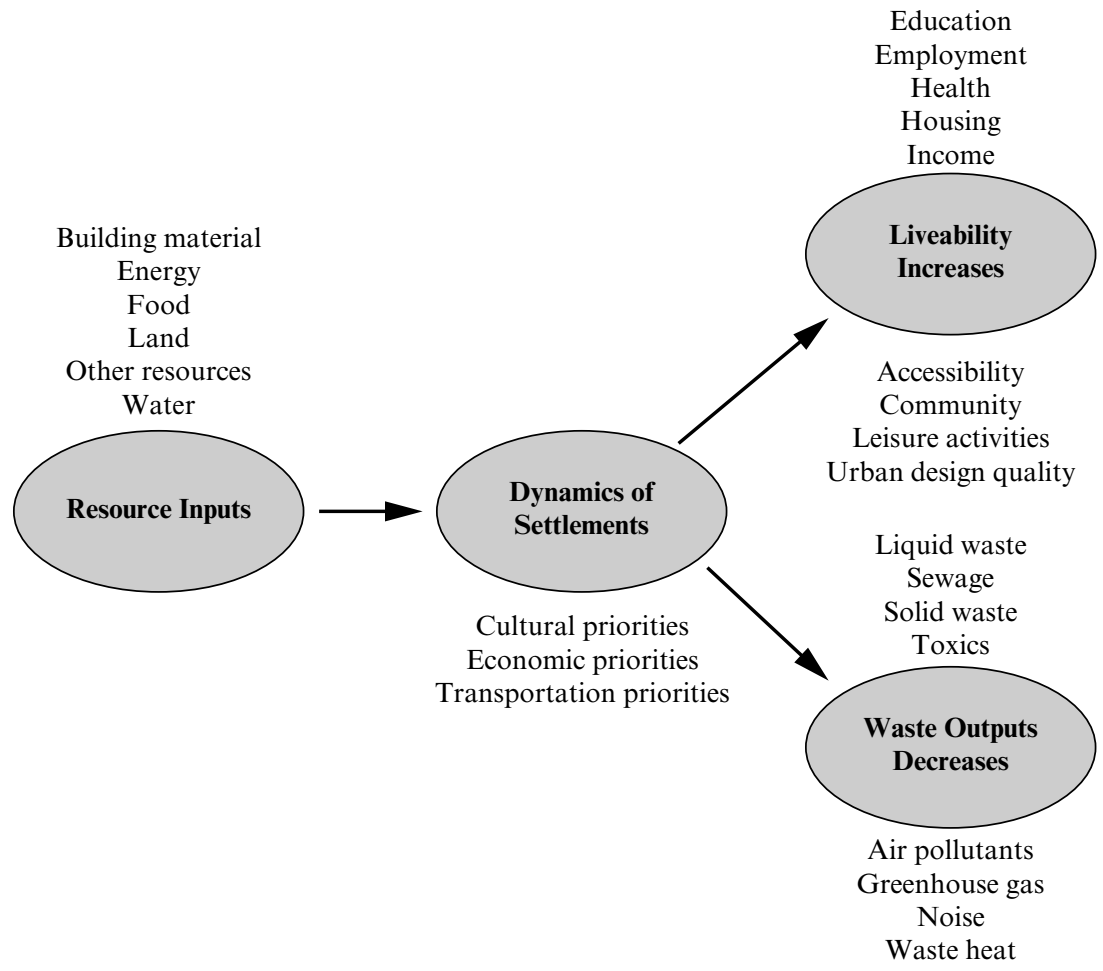

Source: Newman \& Kenworthy, 1999.

\section{Figure 1.1 How sustainability applies to cities}

therefore begin to change infrastructure and land use to adapt (Van Wee et al., 2006).

There are three main city types or urban fabrics based on this principle:

1. Walking cities - pre-historic cities until the 1850s that grew outwards about 3 to $4 \mathrm{~km}$ due to walking speeds and hence were very dense with narrow streets.

2. Transit cities - from the early trains in the 1850s and trams from the 1890s up until the 1950s; cities could grow outwards for 20 or so km due to the speed of transit-enabling long corridors of urban development with dense walkable centres at stations.

3. Automobile cities - post-1950s' cities that grew outwards with the speed of the automobile which extended cities out $50 \mathrm{~km}$ or so. This era ushered in the phenomenon of automobile dependence. 


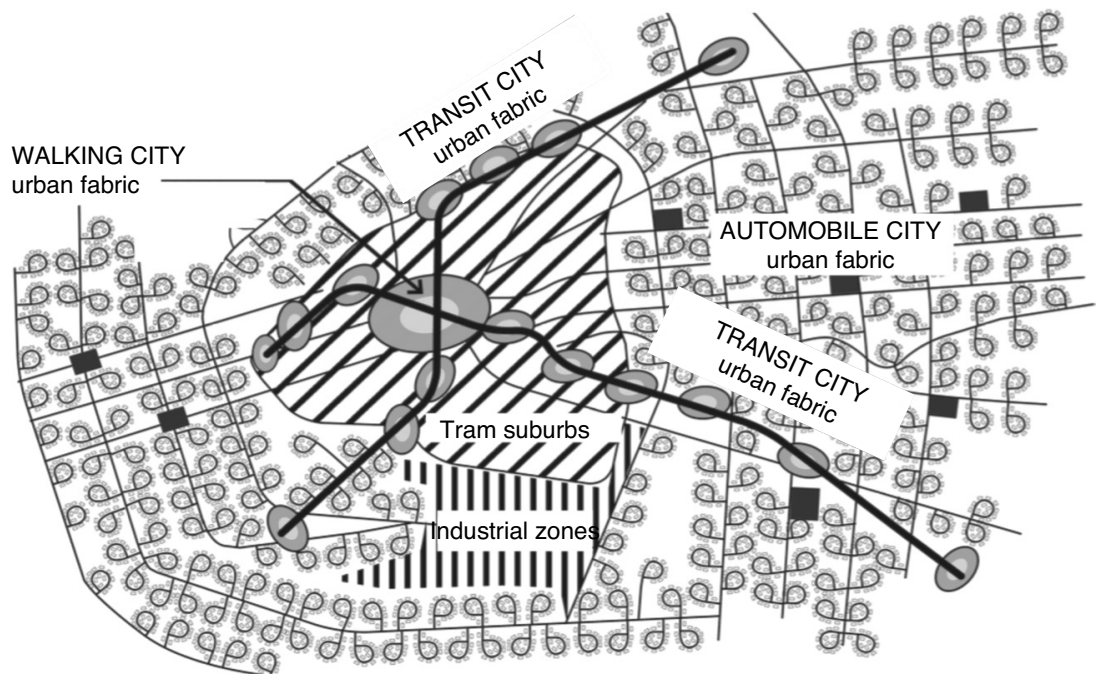

Source: Newman \& Kenworthy, 2015.

Figure 1.2 The combination of walking city, transit city and automobile city urban fabrics

Most cities today have a mixture of all three urban fabrics as shown in Figure 1.2.

\section{Urban Fabrics and Sustainability}

The need for cities to reduce their automobile dependence has become a basis for much consideration as the urban footprint created by cars and their associated suburban sprawl has caused alarm bells around the world (IPCC, 2014). This has become an economic as well as an environmental and social objective. Transport infrastructure that enables less automobile dependence assists in creating more sustainable cities (Newman and Kenworthy, 1999).

The need to reduce automobile dependence has become much more evident with the new phenomenon of 'peak car' (Newman and Kenworthy, 2011). Car use per capita began to plateau and then decline in developed cities in the early part of the 21 st century, followed by cities in the emerging economies (Newman \& Kenworthy, 2015). The decoupling of economic growth from car use and from oil has appeared across the world. The big question becomes whether this trend will continue and what are the tools that will enable it to not just continue but accelerate. 


\section{What is the Next Urban Fabric?}

The automobile city can no longer enable the transport speeds it once had. Car-based traffic congestion has grown to the point that the Marchetti constant is being exceeded. Cities are therefore coming back in rather than sprawling out and are focusing around walking and transit fabric in a polycentric urban form (Newman \& Kenworthy, 2015).

Between 1960 and 2005, the ratio of overall public transport system speed compared to general road traffic increased from 0.55 to 0.70 (Newman \& Kenworthy, 2015). The ratio of rail system speed to general road traffic changed from rail being slower than cars in $1960-0.88$ - to being on average faster in $2005-1.13$ (Newman \& Kenworthy, 2015). Key European, Asian and Australian cities passed the threshold of average speed of rail exceeding road traffic; American and Canadian cities are just below it, though growing fast (Newman \& Kenworthy, 2015).

As well as the transport speed shifts, there have been economic and cultural transformations that are driving this change in transport and land use in cities across the world. The knowledge economy and digital jobs are now focused in city centres where the creative synergies between people occur (Kane, 2010). Old central business districts (CBDs) have been transformed back into functional walking cities. Those which have done this best have attracted the most capital and young talent to work there (Gehl, 2010; Matan \& Newman, 2017). Other activity centres outside the CBDs have also done similar transformations and the linkages between them have become the basis for the revival of the transit city. Universities, health campuses and information and communication technology (ICT) related job clusters have created their own centres for employment, and have attracted housing and transit to link them together.

As with many economic shifts, there is also a cultural dimension that may explain the rapidity of the changes observed above, as well as the demographic complexion of the transition. Young people, especially those involved in knowledge economy jobs, are reducing their car use and switching to alternative transport faster than any other group. This seems to be related to the use of social media devices (Florida, 2010). On transit or walking, and even to an extent while biking, young people are already connected by their smart technology phones and tablets - difficult to do while driving a car. The Davis, Dutzik and Baxandall (2012) report shows that the mobile phone is a far more important device than a car for younger people. This is a cultural revolution that partly underlies the rail revitalization.

Thus, the peak car phenomenon can be explained by the urban fabric theory. The new urban fabric is a combination of the three forms of cities - 
walking, transit and automobile - undergirded by an increased emphasis on ICT systems that can support any of these fabrics. However, the current driving economic and cultural force propels more towards the 'walking city' and 'transit city' urban fabric.

These changes are happening quite quickly and are improving the sustainability of cities as they reduce car use. However, there is a limit to how much the walking and transit city fabric can be renewed for the growing population of many cities. There will be a need for wide-scale redevelopment of the automobile city fabric but the tools for enabling this are not available or are not mainstreamed.

\section{THE PROBLEM WITH TRANSPORT PLANNING AND ASSESSMENT}

The fundamental problem with the past 65 years of town planning and transport planning has been the belief that there is only one type of city the automobile city. The transport models, such as the standard Four Step Transport Model which looks at trip generation, trip distribution, mode choice and route choice (e.g. McNally, 2008), are designed around creating the automobile city, and the statutory town planning regulations generally provide only for the densities, mix, parking and street design of the automobile city.

The Four Step Model predicts road capacity requirements based on household income assumed to have car ownership and car use directly associated with it. However, this is no longer the case with the peak-car phenomenon being driven by the young and wealthy. Town planning similarly has been based on the idea that the young and wealthy will move to spacious outer suburbs. This is reversing, with poor suburbs moving further out and being associated with much higher levels of car use than the wealthy inner suburbs (Committee for Perth, 2014).

Despite tools such as the Four Step Model being out of date, they continue to be used to create more automobile city fabric, while demand for the walking city and transit city urban fabric is increasing. The walking and transit city hubs are the most significant parts of any city economically. It is there that the knowledge economy emerges with its need for intensive people-oriented activity. Walking, cycling and public transport are spatially efficient, so the redevelopment of urban space to enable such locations should be the highest priority. The productive, creative and innovative part of the economy depends on walking and transit city fabric and it is essential that they are recognized, respected and rejuvenated, not damaged by transport and urban plans. By contrast, cars and trucks 
are highly spatially inefficient and thus a consumption economy with its freight needs is focused in the automobile city.

Transport and town planning should foster the innovative economy of a city. The traditional Four Step Transport Model, however, can only assist how to create more automobile city fabric which is no longer the priority. Statutory plans are rarely modified for each type of urban fabric. Transport and town planning sets of tools will need to be recreated to enable all three urban fabrics to achieve levels of service and design outcomes compatible with their walking-, transit- or car-based nature. The chapter therefore seeks to determine how a planning and assessment framework can include the understanding of the factors that mould the cities and how these settlements can be shaped more sustainably.

\section{FOUR KEY TOOLS FOR INFRASTRUCTURE PLANNING AND ASSESSMENT}

The four key tools for infrastructure planning and assessment for the city of today are: using a strategic framework; incorporating wider economic benefits; considering avoidable costs; and understanding value capture and value creation. They are explained in turn below.

\section{Strategic Framework}

Strategic priorities are usually present for any large settlement but indeed within every city, three urban fabrics exist and strategic priorities need to be set for each one of them. By recognizing and respecting the three urban fabrics, created for their particular functions, it becomes possible to regenerate them appropriately using new transport infrastructure. Continuing to see all parts of the city as potential sites for automobile-based infrastructure is an unrealistic modernist assumption about the past that will no longer work in 21st-century cities (Newman \& Kenworthy, 2015).

\section{Strategic priorities for walking city urban fabric}

The new economy of cities requires walkable urban centres if they are to create the intense interactions needed for knowledge production. Thus, walkable centres must first be recognized and then be respected. The best ways to achieve this are:

- Provide walking infrastructure to cope with pedestrian flows that are the highest priority of the transportation system in the area.

- Do not widen streets, or insist on setbacks. 
- Ensure that walking space is sufficient and that traffic signals are timed with long periods for pedestrian flows.

- Enable laneways to be connected and active.

- Encourage high density and mixed use.

- Keep parking to an absolute minimum.

- Ensure there are cycleways on each street in the walking city area apart from pedestrian streets.

- Provide some controls over the amount of traffic permitted to enter and do not allow fast one-way streets with green waves at traffic lights in pedestrian and cyclist areas.

Melbourne, New York and many other cities have instituted plans that respect their walking urban fabric. This has produced spectacular results in terms of increased pedestrian activity and urban functions, as well as demand for more walking city fabric (Gehl, 2010; Matan \& Newman, 2017). Recent studies by health professionals and academics support this walking-based approach to transport infrastructure and planning (The Lancet, 2016).

\section{Strategic priorities for transit city urban fabric}

The high spatial efficiency of the transit city enables the economic outcomes of the knowledge economy as well. Thus, transit urban fabric needs to be recognized and respected in strategic plans. To achieve this, plans should:

- Provide public transit as the major transportation system in the area, supplemented strongly by walking and cycling.

- Ensure that corridors are well connected by fast transit.

- Maintain roads as wide enough for buses and trams but not highcapacity automobile use.

- Optimize all the necessary transit infrastructure to ensure a high quality of service (e.g. passenger information systems, shelters and system maps).

- Provide minimal setbacks on buildings.

- Provide cycleways and pedestrian access on roads leading to all stations.

- Build up the density of centres along train lines and along tram lines.

- Keep parking to a minimum and constrain the amount of car traffic near stations.

Many cities are building up their transit urban fabric through the revival of urban rail and its associated Transit-Oriented Development (Newman et 
al., 2013). The most encouraging trend is to see that in the emerging cities of China and India the highest priority has now shifted to increasing urban rail capacity instead of urban road capacity. These cities have confronted the unresolvable problems of trying to cope with too many automobiles, motorcycles and trucks in cramped urban fabrics that were created and designed for non-motorized modes and transit (Newman et al., 2013).

\section{Strategic priorities for automobile city urban fabric}

The functionality of automobile urban fabric is so embedded into most urban planning and transport planning systems that it hardly needs to be elucidated. In order to maintain such fabric the following elements need to be respected in the plans for these areas:

- Separate functions into clear residential, industrial, retail and other uses, but where it is reasonable, mix the functions.

- Provide large setbacks on all buildings, but avoid inefficiency where noise conditions enable this to be feasible.

- Do not increase densities and mixed use without underpinning them with good public transit systems.

- Protect existing high-capacity roads where needed, especially for freight and where possible include space for mass transit and cycleways.

- Provide sufficient automobile parking without the old suburban mall model of acres of asphalt.

The automobile-dependent suburb will not easily change its fundamental fabric; nor will the associated truck-dependent fabric of warehouses, industries and large-scale shopping/distribution centres that surround most cities. These places will need to be respected for their economic function, as they are not suitable for transit and walking fabric. These large-scale, spatially inefficient land uses are naturally part of an automobile- and truck-related fabric. There are however large tracts of automobile urban fabric that are showing their age and are ready for a new future with less car dependence.

The redevelopment of large, nonviable, car-based shopping malls with their vast parking areas is now underway based on transit urban fabric (Calthorpe, 2010) as is the redevelopment of the greyfields or middle suburbs with more transit urban fabric (Newton et al., 2012). Building a large new walking city in the outer suburbs will be an important step in creating more walking fabric.

Not all automobile urban fabric can be changed into transit fabric but it will need solar electric vehicles, biofuels and methane (solar derived) fuels 
that could enable this transition to occur. Such low-density suburbs also lend themselves to development along the lines of the permaculture and Transition Town movement, with their goals of local self-sufficiency, local food and collecting solar energy (Newton \& Newman, 2013). However, they will still need transport and hence the role of green cars and fuels will be essential for keeping within travel-time budgets as oil-based mobility is phased out.

\section{Benefit-Cost Ratio (BCR) Including Wider Economic Benefits (WEBs)}

Apart from the Four Step Planning Model, the other major transportation planning tool is cost-benefit analysis, which produces the benefit-cost ratio (BCR). Such ratios have been a significant part of transportation decision-making and a $\mathrm{BCR}$ of at least 1.5 is generally required for a project to be considered economically acceptable. The BCRs are dominated by travel-time savings, supplemented by cost savings due to reduced accidents and vehicle emissions. These have been criticized for decades, especially over freeways, as they only represent the time savings on the day the freeway opens, not after it has filled, usually very rapidly filled, and they do not include land use changes induced by the transport infrastructure (Bacon, 1988).

The tools to improve BCRs have begun to appear. Since the Eddington Report in the United Kingdom in 2006 (Department for Transport, 2006) on how transportation impacts on the economy, BCRs can now include what are called wider economic benefits (WEBs) (Schiller et al., 2010). There has been a renewed interest in how transportation BCRs can reflect the wider economic impacts of infrastructure on cities. The WEBs are calculated from the agglomeration economies that are associated with synergies between jobs due to close co-location. These are the benefits derived from face-to-face contact, information exchange, and networking only available to industries working close to each other. They are the closest that urban economists have come to measuring the benefits of density in cities (Trubka, 2012).

When the UK government was planning the biggest piece of infrastructure in modern Europe, the Crossrail project in London, it was only able to find a BCR of just under 1.5 (Newman \& Kenworthy, 2015). As this was in the middle of the downturn related to the global financial crisis, there was a lot of scepticism about whether such a project was a good idea. However, when WEBs were brought to the BCR, the value rose to more than 3 (Newman \& Kenworthy, 2015). The train was obviously going to add dramatically to the economy of London by promoting the knowledgeeconomy-intensive job generation related to the intensive mode of travel into and across central London. The project went ahead. 
The BCRs with WEBs appear to be one of the few tools which link transport assessment to land use. As such, they should be expanded to include residential as well as job-related densities.

\section{Avoidable Costs}

The other decision-making instrument to go along with BCRs is an assessment tool called avoidable costs. This assesses the economic costs and benefits of redevelopment associated with a new project, especially a rail project that can enable redevelopment to occur, and compares it to business-as-usual greenfields urban sprawl.

In terms of the costs of high-density redevelopment versus low-density urban-fringe development, high density looks much more promising:

1. Urban-fringe housing is generally subsidized by governments. In Australia this is around A $\$ 100,000$ per dwelling (Dowling \& Lucas, 2009; Trubka et al., 2010a). Similar data are found in American cities (Burchell et al., 2002; Chatman \& Noland, 2014). In Perth, Western Australia this means A $\$ 45.4$ billion in the next 30 years unless redevelopment occurs on appropriate sites in inner and middle suburbs (Hendrigan \& Newman, 2012).

2. Urban-fringe housing costs the economy hugely in extra transportation costs due to the extra car travel. In Australian cities each dwelling built on the fringe involves an additional $\mathrm{A} \$ 250,000$ in travel cost over the lifetime of the house (Trubka et al., 2010a, b, c). In the next 30 years this will cost Perth A $\$ 133.6$ billion just in time lost to travel. Denser cities have 4-8 percent of their GDP spent on passenger transportation (operating and investment costs for all passenger transportation modes); low-density cities have $12-15$ percent (Kenworthy et al., 1999).

3. Walkable high-density areas have improved health due to greater walkability, and better productivity outcomes due to greater attentiveness and fewer days lost. The healthcare cost reductions of a less sedentary population can be significant (Trubka et al., 2010c; Giles-Corti et al., 2016).

4. Much more of the revenue from residents of high-density areas is spent locally on personal services such as restaurants, childcare and entertainment, rather than on cars and housing, with do-it-yourself tools and materials that invariably go out of the local economy.

Trubka et al. (2010a, b, c) suggest the total benefits of redevelopment would come to around A $\$ 212.9$ billion in savings over greenfields development. 
The same kind of data can be found on all of the car-dependent, lowdensity cities we studied (Newman \& Kenworthy, 2015).

Glaeser and Gyourko (2002) and Glaeser and Gottlieb (2009) conducted studies of the most uncompetitive cities in terms of housing prices and concluded that the largest factor is the lack of high-density zonings that can enable cities to have affordable housing, allowing residents to gain from transport savings, and generating benefits for the city by lowering investment in new infrastructure. Added to this are the economic benefits from the knowledge economy that require dense centres to enable the synergies and project innovations to happen.

Avoidable costs can enable these economic factors to be considered in planning and assessment of transport infrastructure. Most decisions on transport and town planning do not yet include avoidable costs, but if they did they would invariably find that rail projects and their associated urban fabric are more economically beneficial than road projects.

\section{Value Capture and Value Creation}

A fourth factor that is rarely considered in technical economic assessments of infrastructure is how transport systems, especially rail systems, cause land values to increase and hence can be used to help finance the infrastructure. If value-capture potential is included, then the spatially efficient modes of rail, bike and walk can be a focus in order to create more sustainable cities.

Land and property value increases surrounding transit infrastructure have been well documented (Cervero, 1977; Scheurer et al., 1999; Debrezion et al., 2007; Kilpatrick et al., 2007; Duncan, 2010; McIntosh et al., 2013). Many cities have used active value capture mechanisms that simply direct these land value increases back into the project. For example, Copenhagen built its metro by handing over a corridor of former defence land as the basis for funding a public-private partnership (PPP) and many Asian cities such as Hong Kong and Tokyo use government land around stations to build commercial properties that bring in over 20 percent of their revenue (Newman \& Kenworthy, 2015).

Passive value capture is where private beneficiaries around stations help to contribute some of their windfall gains when a rail line is built through the normal taxation system. In this way, if sufficient ongoing funding can be estimated then it is possible to bring private capital in to help build the rail line and use the windfall taxes as a means of financing the system. The main mechanism associated with this passive or indirect value capture is Tax Increment Financing (TIF) and this is well established in many US cities and more recently in the UK (McIntosh et al., 2011, 2013, 2014, 2015). 
Such an approach can enable a city to build the transit and the transit city fabric at the same time, thus allowing the transition away from an automobile-dependent city, and can help create more sustainable cities. Even more involvement of the private sector can also be achieved through value creation rather than value capture approaches where the government's role is managing procurement rather than managing the financing of new urban rail projects (Newman et al., 2016). Such projects are now appearing in North America as the market grows for focused, walkable land development created through urban rail (Newman, 2016).

\section{CONCLUSIONS}

The sustainability agenda for cities is about reducing urban footprints whilst improving liveability. In order to do this, transport infrastructure must be a critical factor as it shapes cities. Reducing automobile dependence has to be a major agenda. By using the urban fabric theory it is possible to understand how cities can be changed into more sustainable outcomes and why the first signs of this through the peak car phenomenon can now be seen. In order to continue or accelerate these processes it is necessary to reform transport and town planning practices. The chapter shows four new approaches which can enable cities to achieve more sustainable outcomes.

\section{REFERENCES}

Bacon, E.N. (1988). Planning and planners in the post-petroleum age: Fundamental issues facing metropolitan development and conservation. Regional Development Dialogue, 9(3), 1-6.

Burchell, R.B., Lowenstein, G., Dolphin, W.R., Downs, A., Seskin, S., Still, K.G., \& Moore, T. (2002). Costs of Sprawl - 2000. Transit Cooperative Research Program (TCRP) Report 74. Transportation Research Board and National Research Council, USA. Washington, DC: National Academy Press. Retrieved from http://onlinepubs.trb.org/onlinepubs/tcrp/tcrp_rpt_74-a.pdf.

Calthorpe, P. (2010). Urbanism in the age of climate change. Washington, DC: Island Press.

Cervero, R. (1977). Transit-induced accessibility and agglomeration benefits: A land market evaluation. Working Paper. Berkeley, CA: Institute of Urban and Regional Development, University of California.

Chatman, D.G., \& Noland, R.B. (2014). Transit service, physical agglomeration and productivity in US metropolitan areas. Urban Studies, 51(5), 917-937.

Committee for Perth. (2014). The real cost of driving to work. Perth, Australia: Committee for Perth. 
Davis, B., Dutzik, T., \& Baxandall, P. (2012). Transportation and the new generation: Why young people are driving less and what it means for transportation policy. Report. San Francisco, CA: Frontier Group and Pirg Education Fund.

Debrezion, G., Pels, E., \& Rietveld, P. (2007). The impact of railway stations on residential and commercial property value: A meta-analysis. Journal of Real Estate, Finance and Economics, 35(2), 161-180.

Department for Transport. (2006). The Eddington Transport Study, UK. Retrieved from http://web.archive.org/web/20111101223415/http://webarchive.nationalar chives.gov.uk/+/http://www.dft.gov.uk/pdf/about/strategy/transportstrategy/edd ingtonstudy/.

Dowling, J., \& Lucas, C. (2009). Suburban sprawl costs billions more. The Sydney Morning Herald, 17 July. Retrieved from http://www.smh.com.au/national/ suburban-sprawl-costs-billions-more-20090716-dmxj.html.

Duncan, M. (2010). The impact of transit-oriented development on housing prices in San Diego, CA. Urban Studies, 48(5), 101-127.

Florida, R. (2010). The great reset: How new ways of living and working drive postcrash prosperity. New York, NY: HarperCollins.

Gehl, J. (2010). Cities for people. Washington, DC: Island Press.

Giles-Corti, B., Vernez-Moudon, A., Reis, R., Turrell, G., Dannenberg, A.L., Badland, H., ... Owen, N. (2016). City planning and population health: A global challenge. The Lancet, 387(10034), corrected proof. Retrieved from http:// dx.doi.org/10.1016/S0140-6736(16)30066-6.

Glaeser, E.L., \& Gottlieb, J.D. (2009). The wealth of cities: Agglomeration economics and spatial equilibrium in the United States. Journal of Economic Literature, 47(4), 983-1028.

Glaeser, E.L., \& Gyourko, J. (2002). The impact of zoning on housing affordability. Working Paper 8835. New York, NY: National Bureau of Economic Research.

Hendrigan, C., \& Newman, P. (2012). A three-mode plan for Perth: Connecting heavy rail, light rail and bus with urban development to achieve 21st-century goals. Report. Perth, Australia: Curtin University Sustainability Policy (CUSP) Institute. Retrieved from http://www.curtin.edu.au/research/cusp/local/docs/ three-mode-plan-perth-draft-public.pdf.

Intergovernmental Panel on Climate Change (IPCC). (2014). Mitigation of Climate Change - Contribution of Working Group 3 to Assessment Report 5. Geneva, Switzerland: IPCC.

Kane, M. (2010). The knowledge economy and public transport. In P. Newman \& J. Scheurer (Eds), The Knowledge Arc light rail: A concept for delivering the next phase of public transport in Perth. Discussion Paper. Perth, Australia: ParsonsBrinkerhoff/Curtin University Sustainability Policy (CUSP) Institute.

Kenworthy, J., \& Laube, F. (2001). Millennium cities database for sustainable transport. Brussels, Belgium: International Association of Public Transport (UITP).

Kenworthy, J., \& Laube, F. with Newman, P., Barter, P., Raad, T., Poboon, C., \& Guia, B. (1999). An international sourcebook of automobile dependence in cities 1960-1990. Boulder, CO: University Press of Colorado.

Kilpatrick, J., Throupe, R., Carruthers, J., \& Krause, A. (2007). The impact of transit corridors on residential property values. Journal of Real Estate Research, 29(3), 303-320.

Marchetti, C. (1994). Anthropological invariants in travel behaviour. Technical Forecasting and Social Change, 47(1), 75-78. 
Matan, A., \& Newman, P. (2017), People cities: The life and legacy of Jan Gehl. Washington, DC: Island Press.

McIntosh, J., Newman, P., Crane, T., \& Mouritz, M. (2011). Alternative funding mechanisms for public transport in Perth: The potential role of value capture. Report. Perth, Australia: Committee for Perth.

McIntosh, J., Newman, P., \& Glazebrook, G. (2013). Why fast trains work: An assessment of a fast regional rail system in Perth, Australia. Journal of Transportation Technologies, 3(2a), 37-47.

McIntosh, J., Trubka R., \& Newman P. (2014). Can value capture work in a car dependent city? Willingness to pay for transit access in Perth, Western Australia. Transportation Research - Part A, 67, 320-339.

McIntosh, J., Trubka, R., \& Newman, P. (2015). Tax Increment Financing Framework for integrated transit and urban renewal projects in car-dependent cities. Urban Policy and Research, 33(1), 37-60.

McNally, M.G. (2008). The Four Step Model. In D.A. Hensher \& K.J. Button (Eds), Handbook of transport modeling (2nd ed., pp. 53-70). Amsterdam, Holland: Elsevier.

Newman, P. (2013). Imagining a future without oil in car-dependent cities and regions. In J. Renne \& B. Fields (Eds), Transport without oil (pp. 203-225). Washington, DC: Island Press.

Newman, P. (2016). Want to build better cities? Get the private sector involved in rail projects. The Conversation. Retrieved from https://theconversation.com/want-tobuild-better-cities-get-the-private-sector-involved-in-rail-projects-52204.

Newman, P.W.G., \& Kenworthy, J.R. (1999). Sustainability and cities: Overcoming automobile dependence. Washington, DC: Island Press.

Newman, P.W.G., \& Kenworthy, J.R. (2006). Urban design and automobile dependence: How much development will make urban centers viable? Opolis, 2(1), 35-52.

Newman, P., \& Kenworthy, J. (2011). Peak car use: Understanding the demise of automobile dependence. World Transport Policy and Practice, 17(2), 32-42.

Newman, P., \& Kenworthy, J. (2015). The end of automobile dependence: How cities are moving beyond car-based planning, Washington, DC: Island Press.

Newman, P., Beatley, T., \& Boyer, H. (2009). Resilient cities. Washington, DC: Island Press.

Newman, P., Jones, E., \& Davies-Slate, S. (2016). The entrepreneur rail model. Curtin University Sustainability Policy Institute. Retrieved from http://www. curtin.edu.au/research/cusp/local/docs/Rail_Model_Report.pdf.

Newman, P., Kenworthy, J., \& Glazebrook, G. (2013). Peak car use and the rise of global rail: Why this is happening and what it means for large and small cities. Journal of Transportation Technologies, 3, 272-287.

Newton, P., \& Newman, P. (2013). The geography of solar PV and a new lowcarbon urban transition theory. Sustainability, 5(6), 2537-2556.

Newton, P., Newman, P., Glackin S., \& Trubka, R. (2012). Greening the greyfields: Unlocking the development potential of middle suburbs in Australian cities. World Academy of Science, Engineering, and Technology, 71, 138-157.

Scheurer, J., Newman, P., \& Kenworthy, J. (1999). Can rail pay? Light rail transit and urban redevelopment with value capture funding and joint development mechanisms. Perth, Australia: Institute for Sustainability and Technology Policy, Murdoch University.

Schiller, P., Bruun, E., \& Kenworthy, J. (2010). An introduction to sustainable transportation: Policy, planning, and implementation. London, UK: Earthscan. 
Standing Advisory Committee for Trunk Road Assessment (SACTRA). (1994). Trunk Roads and the generation of traffic: Report. London, UK: Department of Transport, Government of the United Kingdom.

The Lancet. (2016). Urban design, transport and health. Special Series. Retrieved from http://www.thelancet.com/series/urban-design.

Trubka, R. (2012). Agglomeration economics in Australian cities. (PhD thesis). Curtin University, Perth, Australia.

Trubka, R., Newman, P., \& Bilsborough, D. (2010a). Costs of urban sprawl (1): Infrastructure and transport. Environment Design Guide, 83, 1-6.

Trubka, R., Newman, P., \& Bilsborough, D. (2010b). Costs of urban sprawl (2): Greenhouse gases. Environment Design Guide, 84, 1-16.

Trubka, R., Newman, P., \& Bilsborough, D. (2010c). Costs of urban sprawl (3): Physical activity links to healthcare costs and productivity. Environment Design Guide, 85, 1-13.

Van Wee, B., Rietveld, P., \& Meurs, H. (2006). Is average daily travel-time expenditure constant? In search of explanations for an increase in average travel time. Journal of Transport Geography, 14, 109-122.

Zahavi, Y., \& Talvitie, A. (1980). Regularities in travel time and money expenditures. Transportation Research Record, 750, 13-19. 